\title{
LIPOMA ON THE SOLE OF FOOT: A RARE LOCATION
}

Ramesh Kumar Korumilli ${ }^{1}$, G. Gautham Reddy², D. Murali Krishna ${ }^{3}$, P. Phaniteja ${ }^{4}$, M. Sreeram Reddy ${ }^{5}$

\section{HOW TO CITE THIS ARTICLE:}

Ramesh Kumar Korumilli, G. Gautham Reddy, D. Murali Krishna, P. Phaniteja, M. Sreeram Reddy. "Lipoma on the Sole of Foot: A Rare Location". Journal of Evolution of Medical and Dental Sciences 2015; Vol. 4, Issue 66, August 17; Page: 11560-11562, DOI: $10.14260 /$ jemds/2015/1667

ABSTRACT: Lipomas are benign soft tissue tumors that can occur at any age and frequently on the upper back, neck, shoulder and abdomen. We present a case of lipoma over sole of foot which is an uncommon location.

KEYWORDS: Lipoma, Mass, sole of foot.

INTRODUCTION: Lipoma, described as a universal tumor, is the most common soft tissue tumor and accounts for almost $50 \%$ of all soft-tissue tumors.(1) Lipoma in a foot is extremely rare. We report a case of a lipoma in a $50 \mathrm{yr}$ old female over the sole of foot which is an uncommon location.

CASE REPORT: A 50 year old female patient presented with a history of swelling on the sole of right foot of one year duration which was associated with a past history of trauma. There was no history of pain, fever or discharge from the swelling. On examination a $4 \times 3 \mathrm{~cm}$ swelling noted on the posterior aspect of right foot over the sole, (Fig. 1) with smooth surface, well defined borders and soft in consistency. FNAC was done and a diagnosis of lipoma was made. Excision of the tumor (Fig. 2) was done. The biopsy reported the following findings. A well circumscribed tumor composed of proliferating mature adipocytes. (Fig. 3)

DISCUSSION: Lipomas are the most common soft tissue tumor accounting for almost $50 \%$ of soft tissue tumors.(1) They are mostly seen on upper back, neck, abdomen, chest and shoulder where there is abundant of adipose tissue. They can affect any age group mostly seen in $4^{\text {th }}-6^{\text {th }}$ decade of life.(2)

Lipomas of foot are rare accounting for 3-4\% of tumors of foot,(3) mostly seen on dorsum of foot and ankle. Most common tumors of foot are ganglion cysts, fibromatosis, fibrous histiocytoma and giant cell tumor of tendon sheath.(4,5) Lipomas of foot occur mostly after trauma either due to herniation of adipose tissue through tear in fascia(6) or due to release of cytokines which induce the differentiation of preadipocytes to mature adipocytes.(7) Lipomas can be distinguished from herniation of adipose tissue as herniation of adipose tissue won't grow in size nor surrounded by fibrous capsule.(8) Lipomas of foot are to be differentiated from malignant soft tissue sarcoma of foot such as Kaposi sarcoma, synovial sarcoma or liposarcoma. This case is being reported in view of its rarity. 


\section{CASE REPORT}

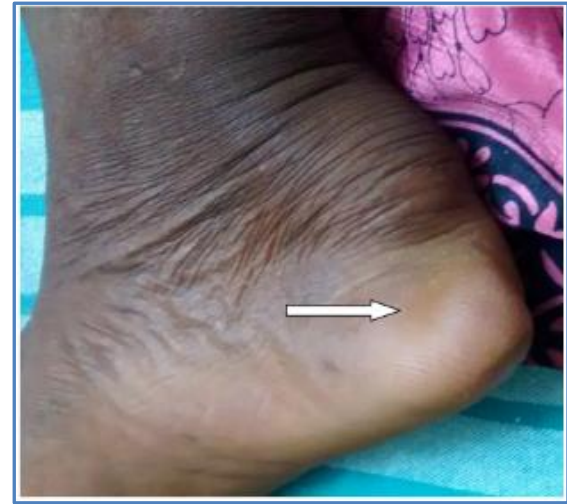

Fig. 1: Swelling over sole of right foot

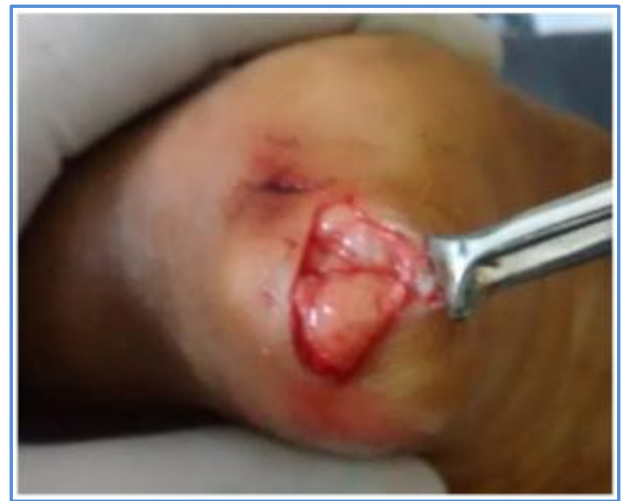

Fig. 2: Intra operative picture of lipoma

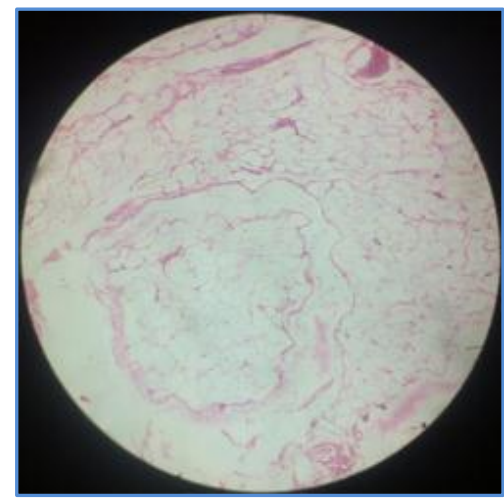

Fig. 3: Histopathological picture

\section{REFERENCES:}

1. Mentzel T. cutaneous lipomatous neoplasms. semin Diagn pathol, 2001: 18: 250-257.

2. Rydholm A, Berg N: size,site and clinical incidence of lipoma: factors in the differential diagnosis of lipoma and sarcoma, Acta orthop scand 1983; 54: 929-934.

3. Bakotic B. W. and Borkowski P. Primary soft-tissue neoplasms of the foot: the clinicopathologic features of 401 cases, Journal of foot and ankle surgery, vol. 40, no.1, pp.28-35, 2001.

4. Ozdemir HM, Yildiz Y, Yilmaz C, Saglik Y: Tumors of the foot and ankle: analysis of 196 cases. J foot Ankle Surg 1997: 36: 403-8.

5. Kransdorf MJ: Benign soft-tissue tumors in a large referral population: distribution of specific diagnosis by age, sex and location. Am J Roentegol 1995; 164: 395-402.

6. Brooke RI, MacGregor AJ: Traumatic pseudolipoma of the buccal mucosa. Oral Surgery, Oral Medicine, Oral pathology, vol.28, no. 2, pp. 223-225, 1969.

7. Signorini M, Campiglio Gl: Posttraumatic lipomas: where do they really come from? Plastic and reconstructive surgery, vol.101, no.3, pp.699-705, 1998.

8. Aust MC, Spies M, Kall S, Gohritz A, Boorboor P, Kolokythas P, Vogt PM: Lipomas after blunt soft tissue trauma:are they real? analysis of 31 cases. Br J Dermatol. 2007: 157: 92-99. 


\section{AUTHORS:}

1. Ramesh Kumar Korumilli

2. G. Gautham Reddy

3. D. Murali Krishna

4. P. Phaniteja

5. M. Sreeram Reddy

\section{PARTICULARS OF CONTRIBUTORS:}

1. Professor \& HOD, Department of Surgery, S. V. S. Medical College, Mahabub Nagar, Telangana.

2. Assistant Professor, Department of Surgery, S. V. S. Medical College, Mahabub Nagar, Telangana.

3. Post Graduate, Department of Surgery, S. V. S. Medical College, Mahabub Nagar, Telangana.

FINANCIAL OR OTHER COMPETING INTERESTS: None
4. Post Graduate, Department of Surgery, S. V. S. Medical College, Mahabub Nagar, Telangana.

5. Post Graduate, Department of Surgery, S. V. S. Medical College, Mahabub Nagar, Telangana.

\section{NAME ADDRESS EMAIL ID OF THE} CORRESPONDING AUTHOR:

Dr. Ramesh Kumar Korumilli, Plot No. 70,

Gruhalaxmi Colony, Old Kakaguda, Secunderabad-500015, Telangana.

E-mail: rameshkorumilli@gmail.com

Date of Submission: 29/07/2015. Date of Peer Review: 30/07/2015. Date of Acceptance: 11/08/2015. Date of Publishing: 17/08/2015. 